\title{
Rethinking Use of Individual Room Air-conditioners in View of COVID 19
}

\author{
Raja Singh $^{1^{*}}$ and Anil Dewan ${ }^{2}$ \\ ${ }^{1 *}$ School of Planning and Architecture, New Delhi-110002, India \\ ${ }^{2}$ Department of Architecture, School of Planning and Architecture, New Delhi-110002, India \\ *rajaphd@spa.ac.in (Corresponding Author)
}

\section{ARTICLE INFORMATION}

Received: April 13, 2020

Revised: July 24, 2020

Accepted: August 10, 2020

Published Online: August 31, 2020

\section{Keywords:}

Room Air Conditioners, Airborne Infection

Control, Disease Spread, Air Changes,

Coronavirus, Tuberculosis

\section{ABSTRACT}

As the World Health Organization is examining the airborne nature of COVID 19, there is past research on other airborne infections which set all encompassing guidelines. Even as more data begins to be available regarding COVID, there is proven spread of airborne disease like tuberculosis being transmitted by this route. As the summer months approach, there is an increased use of Air Conditioners in the tropical regions of the world. India, too being in this part of the world sees an active rise in the indoors which are being air conditioned to meet the thermal comfort requirements of the rising urban population which is spending a large chunk of time indoors. This is coupled with the enforced lockdown which encourages people to stay indoors to prevent the spread of infection. In such situations the use of Room air conditioner requires rethinking as they re-circulate the indoor air without any Fresh air supply into the room. To reduce heat gain and save the electric load of the room AC, people tend to seal the windows further. This paper looks at many possible ways of finding out infection spread in spaces and one of them is used to find out the probability of airborne infection spread in a typical public space. An experiment to validate the same has been conducted in a classroom setup with results analysed. Increased ventilation has been demonstrated to show a lesser probability of infection spread.
Practical Implications of the paper: This short research communication brings forth the issue of use of Room Air conditioners which re-circulates air within a room. This contributes to the spread of airborne infection in the room. As the airborne nature of corona virus is not clear, we have to still follow airborne prevention as later studies may prove a correlation as with SARS 2003. This awareness not only prevents disease, but also enables people achieve thermal comfort in the space responsibly. It also brings to light the bureaucratic ease of procuring individual Room AC units over centralised systems.

\section{Introduction}

The World Health Organization has stated that the Corona virus 2020 is not airborne in nature. There has been some contradictory speculations among the researchers in the world regarding this where it is stated that the chances of airborne transmission are plausible (Doremalen et al., 2020). One major reason for this uncertainty may be the lack of data on the disease transmission dynamics as the priority right now is saving lives of the people. Even if this benefit of doubt is given to the World Health Organization, we must consider that there are proven airborne disease which exist in the world. Tuberculosis being one major infectious disease which propagates through the airborne route of transmission. This disease has a high rate of incidence amounting to 2.8 million new cases every year in India. Other disease like measles also spread through the airborne route.

\section{Thermal Comfort and Ventilation}

In India, as the summer months approach, people will switch on the air conditioners. They will do this to cool the indoor spaces in order to provide adequate thermal comfort for themselves. There is a concern of the balance between providing adequate thermal comfort and the possible spread of air borne infections in the indoor spaces. This concern is particularly valid 
for the Healthcare facilities which have the highest risk of airborne nosocomial infection spread.

Buildings were earlier designed as solely naturally ventilated with complementary window openings, sun shade designs supporting wind movement and the presence of high ventilators along with provisions of ceiling fans. These buildings were simply retrofitted with Room air conditioner units by simply sealing all the window openings and ventilators. Even though these buildings have provisions for opening/closing, they are seldom opened once the air conditioner has been installed.

If we start with educational institutes, the trend of air conditioning started from providing air conditioners in the computer laboratories in order to reduce the equipment heat up and thereby enabling efficient functioning of this computer equipment. Air conditioning leading to cooling of the air was once a luxury in the educational institutes. From the computer labs, the trend went to top management offices followed by conference seminar rooms and finally to faculty rooms. This has today been extended to student classrooms.

\section{Room Air Conditioners: Challenges}

Room air conditioners have one major problem. In order to cool the indoor environment people are rapidly making the airtight. This is done to reduce the heat gain from outside which will increase the air-conditioning load and consequently the electric expenditure. The windows are being shut and the crevices on the edges of the doors and windows are being sealed. By doing so, there is no fresh air supply into the room and the same air within the room gets re-circulated. Room Air Conditioners have no mechanism for providing fresh air supply as the connection between the Indoor and the outdoor unit is just a simple exchange of the refrigerant and the condensate disposal pipe. There is no actual exchange of air using the pipe which connects the indoor and the outdoor unit. Even in the window type, there is a lack of a vent which was present in the earlier models. This situation prevents Air Changes per hour as prescribed by the National Building Code, 2016 (Bureau of Indian Standards, 2016). Research has shown that there is a direct correlation between the high rates of rebreathed air and disease occurrence (Richardson, Morrow, Kalil, Bekker \& Wood, 2014).
Rebreathed air is the air inhaled by a person which has some percentage of the air exhaled by another person. This other person can be one suffering from a contagious airborne disease and his sneeze may be an aerosol suspended in the air. In such situations of recirculation of the same air, there is a high chance of people contracting an infectious airborne disease in case a person with the disease enters the room. This is all the more risky for the healthcare facilities where a Healthcare worker is exposed to a patient in a room where the air is recirculated due to the presence of a Room Air Conditioner which is commonplace in many clinics and hospitals (especially the ones which have been retrofitted by installing individual air conditioners.)

\section{The Bureaucratic Push to Individual Air Conditioners}

The current Central Public Works Guidelines (CPWD) accepts the Room air unit as an acceptable method of air cooling to provide thermal comfort in individual rooms conditioner (Central Public Works Department, Government of India, 2017). CPWD is the national policy body for construction in India apart from being the Project Management Consultant cum contractor for majority of the government projects in India. Due to the ease of tendering and ordering of individual air conditioner units vs. the cumbersome procuring of central AC units, the individual Room air conditioners are being installed in government buildings across India. Sometimes due to administrative ease and to avoid the cumbersome tendering process, educational institutes chose to procure individual Room air conditioner units for various rooms in institutional buildings. This includes installation of split air conditioning units in large assembly spaces where students gather for culture performances or academic exercises. Here the rooms are sealed for retaining the cool are preventing hot air from entering. This is at the cost of Fresh Air supply to these large congregational spaces. This is further supported by the erstwhile DGS\&D (Directorate General of Supplies and Goods, Government of India) rate contract procuring system. This has been replaced by the current GEM (Government E Market Place, Government of India) procurement system which favors the purchase of individual Room Air conditioner systems due to easy purchase and no need 
for tendering. In the General Finance Rules, 2017 which is followed by all the government organisations including the CPWD, the Rule 154 allows purchase of Rs 25000 without a quotation and requires the setting up of a committee for purchases above that amount till Rs. 25,00,000. Purchases above this amount class for tendering and other elaborate processes. In the Online scenario with GEM, purchases till Rs. 50,000 can be made without a quotation or matching quotations (Rule 149) $^{1}$

For the healthcare facilities, this concern arising due to use of Room air conditioners is all the more. There have been suggestions of the use of portable air purifiers in such healthcare facilities. The use of such portable air purifiers is all the more risky as according to the Indian Public Health Standards which states that these filters can pose a bigger threat as they can become the breeding grounds of infection spreads, if not maintained regularly (Ministry of Health and Family Welfare, Goverment of India, 2012). The WHO guidelines on tuberculosis infection prevention and control, 2019 update suggests against the use of portable air filters as they are unable to provide the requisite number of air changes per hour (World Health Organization, 2019).

Another widely discussed method is the upper air ultraviolet germicidal irradiation use for killing the microbes in the space. This current paradigm of killing and sterilizing is being relooked by the researchers who are studying microbiomes in the indoor spaces. They suggest that there are bacteria present in the environment which are of benefit to human well-being (Kembel et al., 2012). In this research, the number of bacteria were more with windows open, but their diversity was of less and more similar to Human disease causing bacteria which have their origin in the human

${ }^{1}$ General Finance Rules, 2017. Ministry of Finance, Department of Expenditure. (https://doe.gov.in/sites/default/files/GFR2017_0.pdf ) skin and human spit. There are also some concerns with the ultraviolet radiations in habitable spaces and their effects on human health have not been fully studied. For low resource settings, this is not always the most cost effective method. Whereas dilution still remains as a cost effective solution for low resource setting. It enables the requisite numbers of air changes per hour required for 'flushing' of the contaminated air in these spaces. The new Guideline 'Severe Acute Respiratory Infection (SARI) Treatment Facility Design created jointly in March 2020 by WHO Architect Anna Silenzi and WHO Highly Infection Pathogens Expert Luca Fontana, suggests the use of dilution ventilation for the creation of makeshift treatment and screening centres for COVID-19. It is being distributed as an online course by the World Health Organization for Building Professsionals (World Health Oraganisation, 2020).

There are some practical implications to doing away with the Room Air Conditioners. This includes the ease of installation and the cost with which the Room Air Conditioner becomes available to the consumer. Another concern is the entry of Pollution into the spaces due to the partial opening of the windows along with a running Room Air Conditioner. This problem can be taken care by the use of a Nano-Filters which prevents the entry of the particulate matter but will not let the air flow to and from the indoor space.

This area requires further attention of the Indoor Air Quality professionals and researchers in India and worldwide. This need for attention is further aggravated by our rising urbanization and the increasing time we are spending indoors.

\section{Experiment: Methodology}

To understand this relationship between ventilation and disease spread, various methods were studied through desk research, these are stated as follows:

Table 1: Comparison between the various methodologies for the study of Airborne Infection Spread in spaces.

\begin{tabular}{|l|l|l|l|l|}
\hline & Method Name & Pros & Cons & Remarks \\
\hline \multirow{2}{*}{1} & $\begin{array}{l}\text { Using Historical Patient Data and } \\
\text { analysing that with the ventilation } \\
\text { changes in a Hospital space }\end{array}$ & $\begin{array}{l}\text { Will reduce dependence on a } \\
\text { surrogate method }\end{array}$ & $\begin{array}{l}\text { Latent infections cant be reported as a huge number of } \\
\text { people have non symptomatic latent infection. }\end{array}$ & \\
\cline { 3 - 4 } & Can be validated with real patient data & Hospital Permissions red tape and conflict of hospital's interest \\
\cline { 3 - 4 } & & Human subjects will require elaborate Ethical clearances. & \\
\hline
\end{tabular}




\begin{tabular}{|c|c|c|c|c|}
\hline 2 & $\begin{array}{l}\text { Using Air Velocity Measurements in } \\
\text { the Room and correlating those with } \\
\text { disease spread models }\end{array}$ & $\begin{array}{l}\text { 1. Easiest to perform with a simple } \\
\text { anemometer and simple algebra. }\end{array}$ & $\begin{array}{l}\text { 1. It only includes the velocity based ventilation and misses } \\
\text { the diffusion based ventilation. }\end{array}$ & \\
\hline \multirow[t]{3}{*}{3} & \multirow[t]{3}{*}{$\begin{array}{l}\text { Using Plate Method and culturing TB } \\
\text { bacteria in a live setting like a DOTS } \\
\text { centre or a TB Hospital }\end{array}$} & \multirow[t]{3}{*}{$\begin{array}{l}\text { 1. Will give the most accurate reading } \\
\text { of bacteria }\end{array}$} & TB takes 3 weeks to culture. Huge waiting time per sample. & \multirow{3}{*}{$\begin{array}{l}\text { Only } \\
\text { BS I } \\
\text { generally } \\
\text { available. }\end{array}$} \\
\hline & & & $\begin{array}{l}\text { The handling of TB bacteria requires BS III labs and } \\
\text { elaborate safety requirements. The experimenter is at risk. }\end{array}$ & \\
\hline & & & $\begin{array}{l}\text { Sampling only possible where there is a possibility of TB } \\
\text { Bacteria suspended in the space. }\end{array}$ & \\
\hline 4 & $\begin{array}{l}\text { Questionnaire based analysis where } \\
\text { the inhabitants will report disease } \\
\text { incidence and ventilation scenario }\end{array}$ & 1. Easy to perform. & $\begin{array}{l}\text { 1. Accuracy is an issue due to the latency of the disease and } \\
\text { people who have TB may not report it. }\end{array}$ & \begin{tabular}{|l} 
Can \\
work for \\
common \\
cold type \\
harmless \\
diseases \\
only.
\end{tabular} \\
\hline 5 & $\begin{array}{l}\text { ACH study in a space and linking } \\
\text { that with the Well Riley and Rudnick } \\
\text { Milton Model. }\end{array}$ & $\begin{array}{l}\text { 1. It is accurate in establishing the Air } \\
\text { Changes per hour using both the } \\
\text { methods (tracer and biomarker) } \\
\text { 2. Due to a experimentally established } \\
\text { link between infection spread and Air } \\
\text { Changes, it is a very reliable method. }\end{array}$ & 1. Not as reliable as real time diagnosis. & \\
\hline
\end{tabular}

A preliminary study based on the fifth method in the Table 1 stated above. In this method, only the $\mathrm{ACH}$ study with the Wells Riley model was studied.

Experiment Details: Location: Ground Floor Classroom @SPA Architecture Block. The class size was of typical 30-50 student configuration. The experiment was performed in an empty classroom. The classroom has 2 stand-alone air conditioners and the windows of the room were closed. It was a window based air conditioner (two tonnage) without vents.

\section{Apparatus:}

1. Carbon Dioxide Cylinder: Luxfer Uttam Aluminium Cylinder 5 KG Gas

\section{NDIR Based $\mathrm{CO}_{2}$ Sensor}

Temperature Range: $0^{\circ} \mathrm{C}$ to $50^{\circ} \mathrm{C}$; Resolution: $0.1^{\circ} \mathrm{C}$; Accuracy: $\pm 0.8^{\circ} \mathrm{C}$;

Humidity Range: $10 \%$ to $90 \%$ R.H; Resolution: $0.1 \%$ R.H; Accuracy: 70\% RH

$\mathrm{CO}_{2}$ Range: 0 to $4,000 \mathrm{ppm}$; Resolution: 1ppm; Accuracy: \pm 40 ppm

Display: LCD size: $60 \mathrm{~mm}$ x $50 \mathrm{~mm}$; Operating Temperature: $0^{\circ} \mathrm{C}$ to $50^{\circ} \mathrm{C}$; Operating

Humidity: Less than 90\% R.H; Data Output: RS 232/ USB PC computer interface
Memory Card: SD memory card. 1GB to 16GB; Power Supply: DC $1.5 \mathrm{~V}$ battery

Accessories: Instruction manual, $\mathrm{CO}_{2}$ probe, $\mathrm{AC}$ to $\mathrm{DC}$ $9 \mathrm{~V}$ adapter, Main meter hanging unit (with sticker), $\mathrm{CO}_{2}$ hanging unit ( with sticker )

The method followed for the experiment is as follows: Room is on Normal Status, like used everyday.

Step 1: Room filled with $\mathrm{CO}_{2}$ in the centre.

Step 2: The $\mathrm{CO}_{2}$ meter switched on with Data Logging.

Step 3: Data Taken till $\mathrm{CO}_{2}$ reaches $450 \mathrm{ppm}$

Step 3: The data is tabulated and analysed.

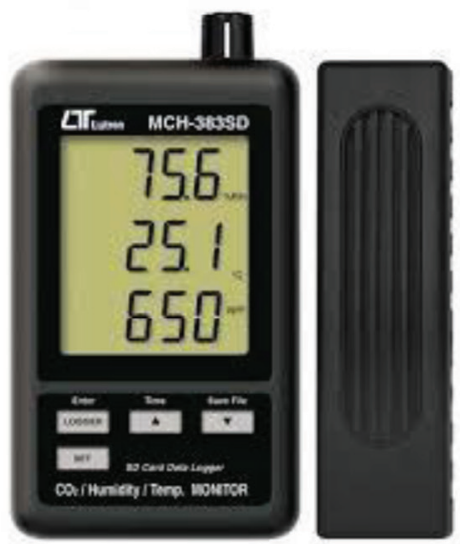

Figure 1: The Carbon Dioxide meter used in the experiment based on NDIR Sensor. 


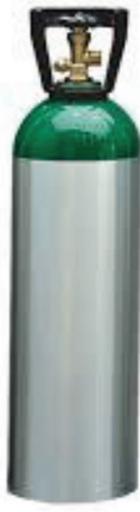

Figure 2: The Carbon Dioxide safety cylinder used in the experiment.

Table 2: The Time on the $\mathrm{X}$ axis and the Carbon Dioxide Concentration in PPM on the $\mathrm{Y}$ axis. This table shows the rate of dissipation of the gas which is used to ascertain the $\mathrm{ACH}$ in the space. This is the tracer gas method.

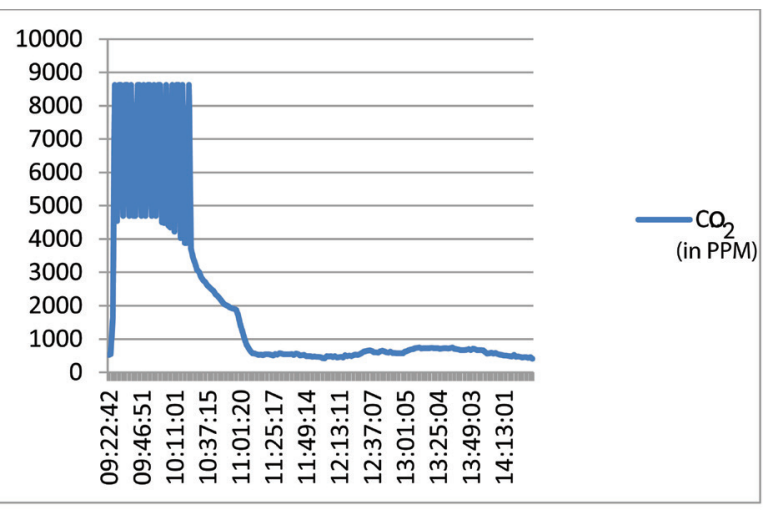

\section{Results and Discussion:}

In 1.88 hours, the $\mathrm{CO}_{2}$ level reaches the ambient Level. Therefore the Air is changing at a rate of $0.5 \mathrm{ACH}$ per hour.

The NBC standard for classrooms is $5-7 \mathrm{ACH}$

Table 3: The Initial and the end PPM entries used to find out the dissipation rate of the gas in the indoor space

\begin{tabular}{|l|l|}
\hline Time Entry & $\mathbf{C O}_{2}$ PPM \\
\hline $10: 23$ & 3719 \\
\hline $12: 16$ & 450 \\
\hline
\end{tabular}

(Carbon dioxide exists in the Earth's 1244 atmosphere as a trace gas at a concentration of about 0.045 percent (450 ppm) by volume. ISHRAE 2019 IEQ Standard)

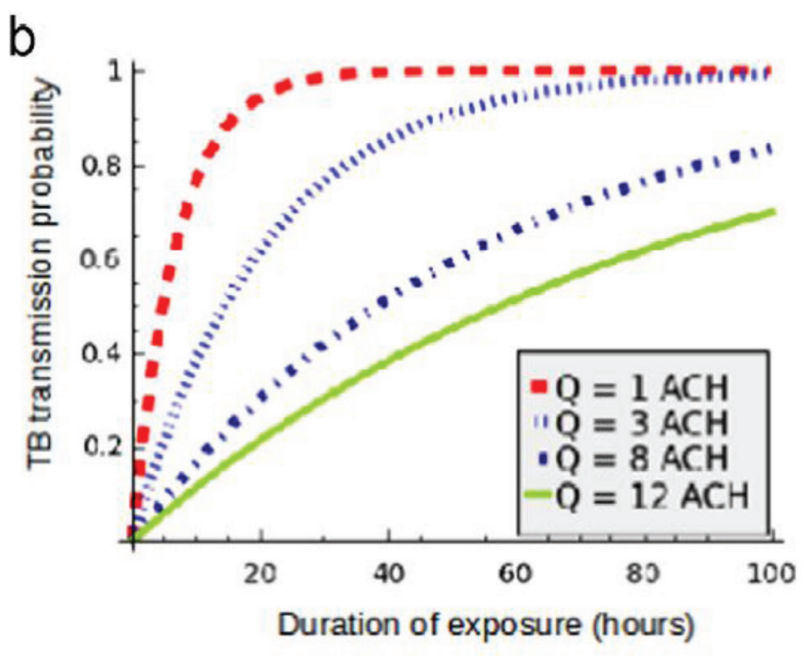

Figure 3: Issarow, C. M., Mulder, N., \& Wood, R. (2015). Modelling the risk of airborne infectious disease using exhaled air. Journal of Theoretical Biology, 372, 100-106. doi:10.1016/j. jtbi.2015.02.010.

As per the above Figure 3, it has been mathematically modelled that the risk of airborne infection is the greatest when the $\mathrm{ACH}$ is 1 or less. In our classroom, the $\mathrm{ACH}$ was 0.5 and the probability of TB transmission is the highest when compared to a scenario with a higher $\mathrm{ACH}$. This classroom is therefore a space where public gathering should be avoided.

A possible solution to this problem is to enable hybrid ventilation where a window is kept open along with the air conditioner so that there is an increased $\mathrm{ACH}$ and a lesser probability of airborne infection spread. Our conditioning of hermetically sealing indoor spaces to prevent electricity loss due to temperature increase has to be rethought as the cost of recirculated air will be an increased risk of disease spread in spaces.

\section{Funding and Conflict of Interest}

No funding was taken for this study. The author and the co-author declare to have no conflict of interest.

\section{References}

Bureau of Indian Standards (2016). SP(7) National Building Code. New Delhi : Bureau of Indian Standard. (Bureau of Indian Standards, 2016).

Central Public Works Department, Government of India (2017). General Specifications for Heating, Ventilation 
\& Air-Conditioning (HVAC) Works. New Delhi: Central Public Works Department, Government of India.

Doremalen, N.V., et al. (2020). Aerosol and Surface Stability of SARS-CoV-2 as Compared with SARSCoV-1. The New England Journal of Medicine, 382(16), 1564-1567.

https://doi.org/10.1056/NEJMc2004973.

Issarow, C.M., Mulder, N., \& Wood, R. (2015). Modelling the risk of airborne infectious disease using exhaled air. Journal of Theoretical Biology, 372, 100-106. https://doi.org/10.1016/j.jtbi.2015.02.010

Kembel, S.W., et al. (2012). Architectural design influences the diversity and structure of the built environment microbiome. The ISME Journal, 6, 1469-1479. https://doi.org/10.1038/ismej.2011.211
Ministry of Health and Family Welfare, Goverment of India (2012). Indian Public Health Standard. New Delhi: Ministry of Health and Family Welfare, Goverment of India.

Richardson, E.T., Morrow, C.D., Kalil, D.B., Bekker, L.G., \& Wood, R. (2014). Shared Air: A Renewed Focus on Ventilation for the Prevention of Tuberculosis Transmission. PLOS ONE 9(5): e96334. https://doi.org/10.1371/journal.pone.0096334

World Health Organization (2019). WHO guidelines on tuberculosis infection prevention and control, 2019 update. Geneva : WHO.

World Health Oraganisation (2020). Severe Acute Respiratory Infection (SARI) Treatment Facility Design. World Health Oraganisation.

\section{早 CHITKARA}

\section{Creative Space}

Chitkara University, Saraswati Kendra, SCO 160-161, Sector 9-C, Chandigarh, 160009, India

Volume 8, Issue 1

July 2020

ISSN 2321-3892

Copyright: [C 2020 Raja Singh and Anil Dewan] This is an Open Access article published in Creative Space (Creat. Sp.) by Chitkara University Publications. It is published with a Creative Commons Attribution- CC-BY 4.0 International License. This license permits unrestricted use, distribution, and reproduction in any medium, provided the original author and source are credited. 